\title{
Double Layer Socket Preservation Technique Associated with Xenogenous Bone Graft and Polypropylene Membrane: A Case Report
}

\section{Bruno Santana Freitas*, Felipe Andres Ortiz Poblete, Sergio Charifker Ribeiro Martins, Leandro Lécio de Lima Sousa, Andre Hamar Braga and Bruno Goes da Costa Pinto}

Department of Oral Implantology and Dental Prosthetics - ICS UniFunorte - Centro

Universitário Faculdades Unidas Norte de Minas, Recife, PE, Brazil

*Corresponding Author: Bruno Santana Freitas, Department of Oral Implantology and Dental Prosthetics - ICS UniFunorte - Centro Universitário Faculdades Unidas

Norte de Minas, Recife, PE, Brazil.
Received: November 26, 2021

Published: December 31, 2021

(C) All rights are reserved by Bruno Santana

Freitas., et al.

\begin{abstract}
With the demand for tooth/gum aesthetics in implant-supported rehabilitations, the surgeon, whether an implant specialist or not, increasingly needs to be mindful of proper care for socket preservation following extraction. The paper presented here reports the case of a male patient who manifested dental impairment of the Upper Left First Molar (tooth \#26) [in FDI notation]; following tomographic analysis and after reaching a consen- sus with the patient, the decision was made to extract said tooth and preserve the socket for subsequent implant placement. The aim of the case report is to present a clinical case of alveolar ridge preservation through the "Double Layer Socket Preservation" technique, a technique created by Barry Barthee, whereby a xenogenous graft under an xenogenous type III collagen membrane was combined with a polypropylene barrier. Following research and study results on the subject, it was concluded that by applying this technique, the alveolar ridge is greatly preserved and bone volume is maintained, both of which are very important factors for good health of the tissues surrounding the implant and consequent increase in the survival of the implant itself.
\end{abstract}

Keywords: Ridge Preservation; Double Layer; Collagen Membrane; Polypropylene; Polypropylene Barrier

\section{Introduction}

Even today, implant dentists seek alveolar ridge preservation after extraction, and this is due to the effort to reduce post-surgical bone remodeling, given that the greatest interest is in maintaining the framework in such a way as to be sufficient for future rehabilitations, whether implant-supported or not [1-3].

According to Araújo and Lindhe (2005) and Araújo., et al. (2015), the remodeling that occurs after tooth extraction is known as alveolar resorption. This repair process occurs naturally after there has been damage to the local tissue, which leads to a series of changes in such tissue, causing a visible change in volume and re- ducing the adjacent tissues, which is related to the loss of function of this target bone. For Schropp., et al. (2003), the period of greatest bone resorption (changes of up to $50 \%$ in the alveolar ridge) occurs within the first year after tooth extraction, and the first three months are the period of greatest osteoclastic activity [4-6].

In recent years, there has been increasing demand and concern for the functional and aesthetic rehabilitation of partial and total edentulous patients through osseointegrated implants; traditional and conventional procedures advise a period of two to three months of bone remodeling in the cavity after extraction, in addition to a period of three to six months (or longer) of healing without masticatory loads, for successful osseointegration of the implant. It 
is known that there are peri-implant defects, extensive horizontal and vertical losses, with low thickness in the buccal bone plate being one of the main causes of bone defects. Reconstruction of the alveolar process through guided bone regeneration (GBR) with a non-resorbable polypropylene barrier reduces the severity of bone defects and provides the ideal format for patient rehabilitation. The barriers should show integration by the host's tissues, as well as semipermeability and biocompatibility. They must be easy to handle and be capable of maintaining the space without damaging the tissues, regardless of their raw material or whether or not they are resorbable, and must be made of synthetic biocompatible material $[7,8]$.

Schropp., et al. (2003), Araújo., et al. (2015); Misawa., et al. (2016) state that the resorption pattern in the molar and premolar region is greater when compared to the anterior region. However, if we consider bone characteristics of the anterior region of the maxilla, where we commonly find a thin buccal wall $<1.0 \mathrm{~mm}$, as well as its major aesthetic relevance, bone remodeling - even if statistically smaller - would be critical, as it would directly interfere in future rehabilitation with implant-supported restorations and in the tooth/gum aesthetics of the region (Chappuis., et al. 2017). Not to mention that other factors, just as important as those mentioned above, can change the resorption process, presenting themselves differently among patients, since the patients themselves are subject to several factors, whether local or systemic, such as: the presence of infections, the existence of previous periodontal disease, diabetes, hematological problems, dental trauma injuries, parafunctional habits, the reason for tooth extraction, or the integrity of the buccal cortical bone (MacBeth., et al. 2016) [6,9-12].

As it is widely known, the blood clot is of the utmost importance in the bone repair process, since it is rich in platelets and bone morphogenetic proteins, and is one of the growth factors that favor alveolar ridge regeneration. From this clot, a fibrin network is formed, which provides resistance. Therefore, when using a resorbable and impermeable polypropylene barrier, undifferentiated clot cells produce bone tissue without penetration of epithelial and connective tissue, and with no need for fixation devices $[13,14]$.

The term "socket preservation" emerged to describe the process of slowing down the natural resorption of this bone. According to Sclar (2004), the aforementioned term represents "all surgical techniques that aim to preserve the maximum volume and architecture of hard and soft tissues in the extraction site, in order to optimize the aesthetics and function of the future implant-supported restoration". For authors such as Weng., et al. (2011), when the ridge is not properly preserved, a smaller amount of healthy bone can be found, resulting in inadequate aesthetics in the region and leading to the need for bone grafting, which in the posterior region has a 10 times higher prevalence during rehabilitation, compared to treatment with prior ridge preservation $[15,16]$.

Bezerra., et al. (2021) concluded in their study that the alveolar ridge is preserved and bone volume is maintained when applying the double layer membrane technique after tooth extraction, noting that this preservation is of paramount importance for good peri-implant health, as well as for a longer immediate implant survival rate. They also observed that through the double layer technique, the bone preservation obtained is extremely important as a support for the mucous tissue and maintenance of the papillae, resulting in outstanding aesthetic and functional results for the patient [17].

The use of a polypropylene barrier exposed to the oral environment helps maintain the alveolar ridge longitudinally. Not only does connective tissue grow, but bone tissue grows as well. The ease of access and manipulation by the dentist and the involvement of tissue physiology make this method an alternative method that can help minimize bone resorption and even secure clots. This barrier is an important means of great help in clinical dental practice [18].

\section{Proposition}

The aim of this study is to present a clinical case of socket preservation using a xenogenous graft under a xenogenous type-III collagen membrane and a polypropylene barrier.

\section{Case Report}

Patient E.G.N., 63 years old, male, presents a compromised Upper Left First Molar (tooth \#26) [in FDI notation]. Supplementary exams were requested, and no changes were observed after initial analysis in Cone Beam Computed Tomography (Figure 1).

During the analysis, we verified the need to remove said tooth, whereby we chose to extract it in a minimally traumatic (Figure 2), way in order to preserve the buccal bone plate, followed by preservation of the socket (Figure 3 and 4), with heterogeneous graft associated with a collagen membrane and polypropylene barrier, according to the "double layer socket preservation" technique. 


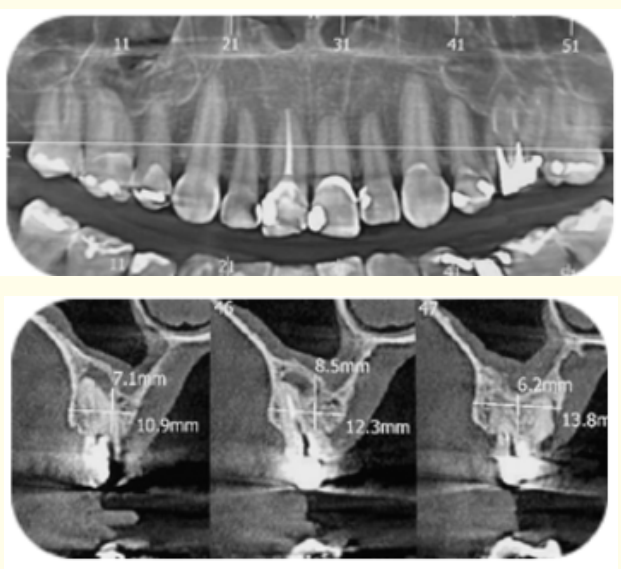

Figure 1: Panoramic view and tooth CT imaging initial.

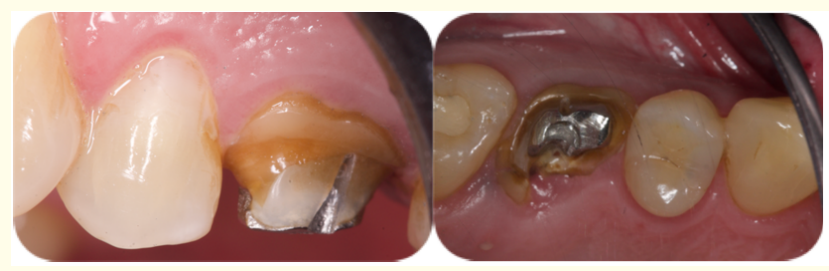

Figure 2: Buccal and occlusal views of tooth \#26 [FDI notation].

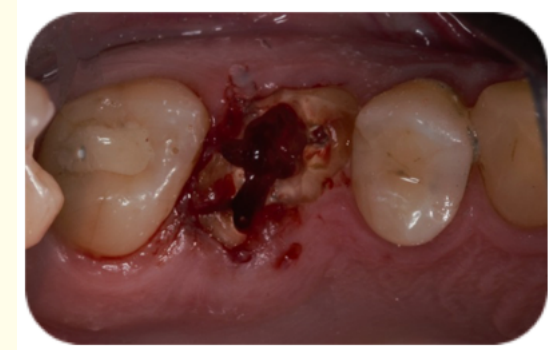

Figure 3: Root section.

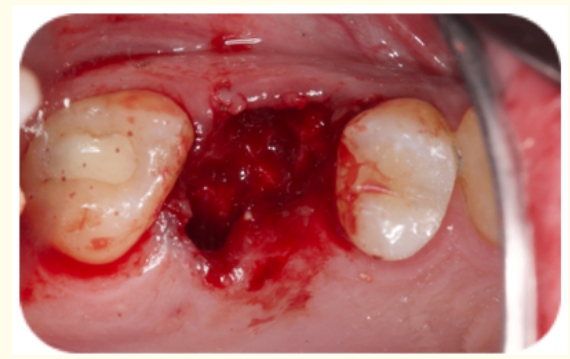

Figure 4: Minimally traumatic extraction.
After the minimally traumatic extraction, a heterogeneous bone graft (Lumina Bone Fine Granulation - Critéria Biomaterials, São Carlos, SP - Brazil), non-reticulated bovine type 1 and 3 collagen membrane (Lumina Coat - Critéria Biomaterials, São Carlos, SP Brazil) (Figure 5 and 6), in association with a polypropylene barrier (Poliprop - Consulmat Smart Materials, São Carlos, SP - Brazil), (Figure 5, 6, 7 and 8).

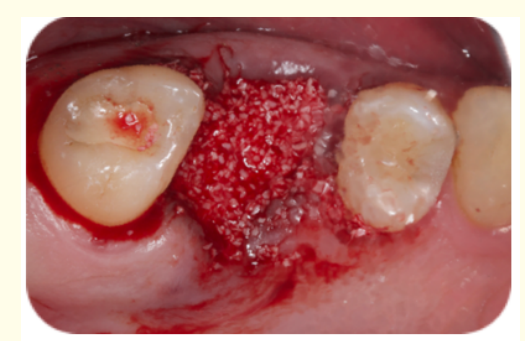

Figure 5: Xenogenous bone graft

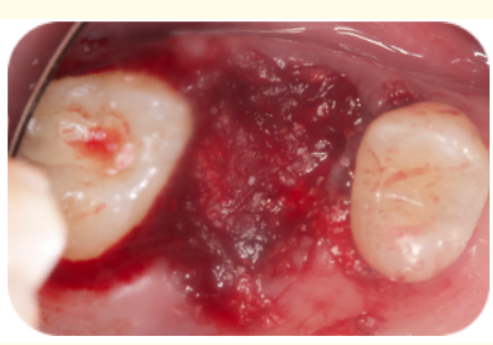

Figure 6: Bovine collagen membrane.

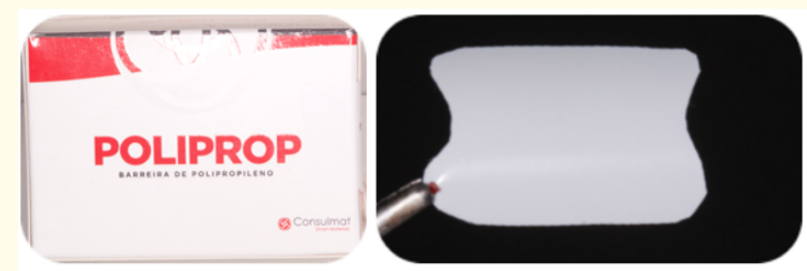

Figure 7: Polypropylene Barrier.

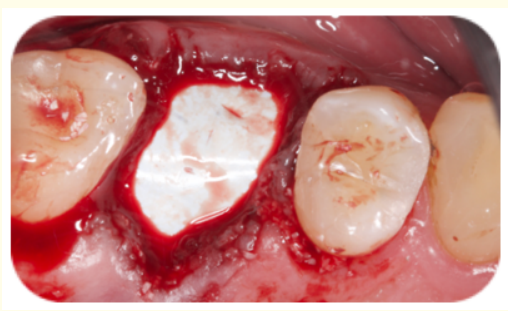

Figure 8: Polypropylene Barrier in place. 


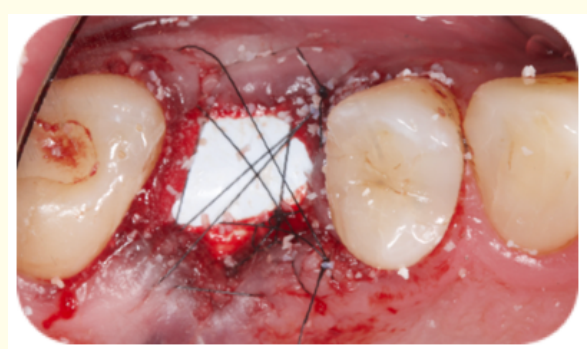

Figure 9: Using suture technique In Place.

Extraoral antisepsis was performed using $2 \%$ chlorhexidine. We performed an infiltrative anesthetic technique with articaine anesthetic (100.000:1 dilution). We did not observe any need for flap opening, followed by alveolar extraction using an extraction kit. After removing the tooth, we performed curettage to remove any fragmented residue, as well to stimulate bleeding of the alveolar process.

Then, we filled the alveolar space between the buccal wall with bone graft of het- erogeneous origin, and a bovine type- 1 and type3 collagen membrane, closing it with a Polypropylene barrier. We sutured the site using 5-0 micro-nylon suture (Microsuture, São Paulo, SP - Brazil), using the crisscross technique in the socket (Figure 9).

The polypropylene barrier was also removed at 28 days (Figure 10), whereby a satisfactory evolution of the clinical aspect after surgery was readily noticeable (Figure 11), showing a possible advantage in applying the technique with regard to structural and volumetric maintenance of the tissues adjacent to the implant (Figure 12).

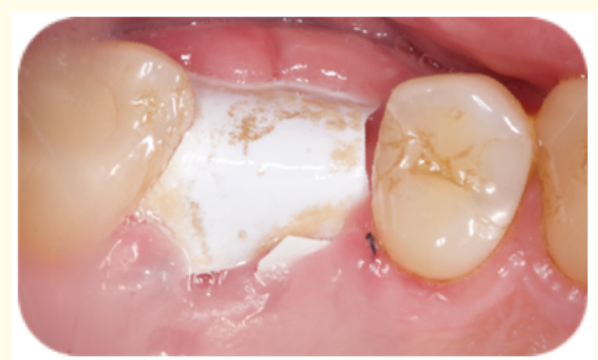

Figure 10: After 28 days with remove suture.

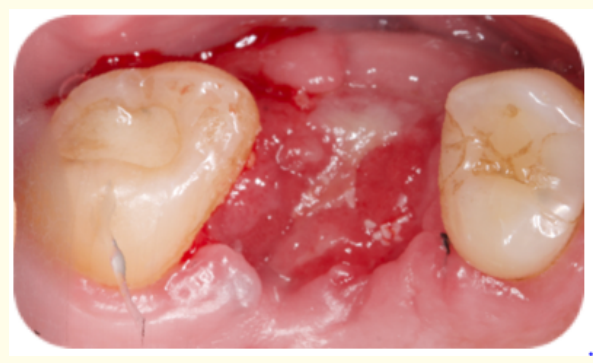

Figure 11: Polypropylene barrier remove.

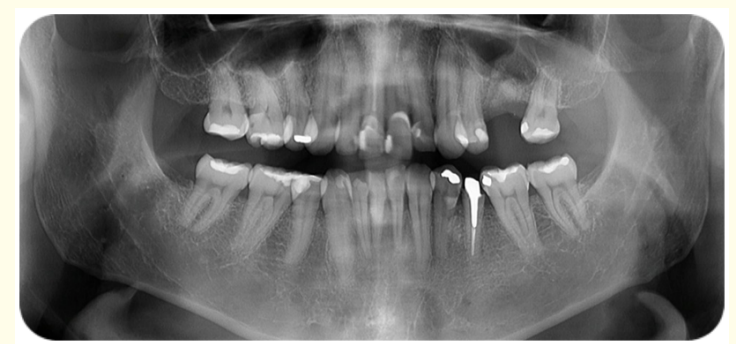

Figure 12: Panoramic view RX imaging final.

\section{Discussion}

Through procedures aimed at promoting guided bone regeneration, it is possible to physiologically maintain the thickness and height of the edges, even if graft materials are needed to fill the alveoli.

The principle of regeneration of certain tissues by cells with this regenerative capacity upon colonizing the defect during repair is what defines guided bone regeneration; this occurs with the mechanical exclusion of soft tissue, allowing osteogenic cells, to promote the formation of bone tissue. Accordingly, the use of polypropylene barriers in the oral cavity contributes toward stabilizing the clot within the alveolus, and stimulates the regeneration of its post-extraction edges [7].

What determines the clinical success or failure of a treatment with dental implants is the absence of pain, signs of infection or mobility, with osseointegration being observed through X-ray, i.e., without any peri-implant radiolucent halo, according to Clementini (2011) and Guerrero (2016). For Mezzomo (2011) and Primo (2011), many researchers recommend regenerative methods using 
biomaterials to maintain the bone ridge, and aimed at maintaining the anatomy and volume of the alveolar bone. Thus, the use of a polypropylene barrier is characterized as a highly feasible option, showing very satisfactory results [19-22].

Current studies demonstrate that guided bone and tissue regeneration techniques can be used successfully when using both resorbable and non-resorbable membranes [23,26].

According to Martins., et al. (2020), the mere extraction of a tooth already promotes a chain of reactions that increase bone remodeling and alveolar ridge compression; the technique used for this extraction can increase or decrease the amount of bone loss. A minimally invasive technique combined with bone grafts tends to improve the amount of peri-implant soft tissue, which increases the likelihood of achieving an excellent aesthetic result. Within the scope of oral surgery, tooth extraction is one of the most common procedures, and is associated with alveolar bone loss; it should be considered that no extraction technique is completely atraumatic. Currently, there are several techniques and instruments that are revolutionizing the fields of oral and maxillofacial surgery, seeking to increasingly reduce trauma related to tooth extraction $[24,25]$.

Cavestro., et al. (2018), in their case report, state that oral rehabilitation with dental implants is currently a highly predictable treatment alternative. Therefore, it was concluded that the installation of an impermeable membrane made of $100 \%$ polypropylene contributed to the preservation of the clot within the post-extraction socket, which maintained the alveolar ridges and promoted guided bone regeneration, as it promoted the isolation of the area to be regenerated, acting as a mechanical barrier and preventing epithelial and connective-tissue growth [26].

\section{Conclusion}

Through this case report, the conclusion was reached that when applying the Double Layer Socket Preservation technique after extraction, it is possible to maintain the alveolar ridge as well as preserve bone volume, both of which are key factors for good periimplant health and consequent increase in implant survival. With such bone preservation, obtained through the aforementioned technique, excellent aesthetic and functional results are obtained, due to the support given to the mucous tissue and maintenance of the papillae. Further studies on this technique need to be conducted to expand our understanding of the results obtained.

\section{Bibliography}

1. Elson Tadeu Fernandes de Oliveira, R. H. B. de F. I. P. de M. Preser- vação alveolar em área estética em paciente vítima de traumatismo: um relato de caso. Archives of Health Investigation (2018).

2. Ashman A. "Ridge preservation: the future practice of dentistry". Dental economics 85.8 (1995): 80-83.

3. Bartee BK. "Extraction site reconstruction for alveolar ridge preservation. Part 1: rationale and materials selection". Journal of Oral Implantology 27.4 (2001):187-193.

4. Araújo MG and Lindhe J. "Dimensional ridge alterations following tooth extraction. An experimental study in the dog". Journal of Clinical Periodontology 32.2 (2005): 212-218.

5. Araújo MG., et al. "Ridge alterations following grafting of fresh extraction sockets in man: A randomized clinical trial”. Clinical Oral Implants Research 26.4 (2015): 407-412.

6. Schropp L., et al. "Bone healing and soft tissue contour changes following single-tooth extraction: a clinical and radiographic 12-month prospective study". International Journal of Periodontics and Restorative Dentistry 23 (2003): 313-323.

7. Santos SP., et al. "Regeneração óssea guiada (rgo) com uso de membrana não reabsorvível de polipropileno-bone heal em alvéolo pós-exodontia - relato de caso". Full Dentistry in Science 7.28 (2016): 42-48.

8. Santos, R. G.e Neder VM. "Regeneração Óssea Guiada Pós-Exodontia - Barreira de Polipropileno: Relato de Caso". Revista de Odontologia da Braz Cubas 10.1 (2020).

9. Araujo MG., et al. "Alveolar socket healing: what can we learn?" Periodontology 200068 (2015): 122-134.

10. Misawa M., et al. "The alveolar process following single-tooth ex- traction: a study of maxillary incisor and premolar sites in man". Clinical Oral Implants Research 27 (2016): 884-889.

11. Chappuis V., et al. "Clinical relevance of dimensional bone and soft tissue alterations post-extraction in esthetic sites". Periodontology 200073 (2017): 73-83.

12. MacBeth N., et al. "Hard and soft tissue change following alveolar ridge preserva- tion: a systematic review". Clinical Oral Inplants Research 28.8 (2016): 982-1004.

13. Borges FL., et al. "Simultaneous Sinus Membrane Elevation and Dental Implant Placement Without Bone Graft:A 6-Month 
Follow-up Study". Journal of Periodontology 82.3 (2011): 403412.

14. Zeppini LAS. "Barreira de polipropileno-Uma nova abordagem para regeneração óssea guiada (ROG)”. Rev Odontologia (ATO). 14.5 (2014): 301-307.

15. Sclar AG. "Strategies for management of single-tooth extraction sites in aesthetic implant therapy". Journal of Oral and Maxillofacial Surgery 62.9 (2004): 90-105.

16. Weng D., et al. "Are socket and ridge preservation techniques at the day of tooth extraction efficient in maintaining the tissues of the alveolar ridge?". 4 (2011): 59.

17. Bezerra GM., et al. "Immediate Implant Placement and Double Layer Socket Preservation Associated with Mix of Xenograft and Particulate Autogenous Bone Graft: A Case Report". SVOA Dentistry 2:4 (2021): 131-138.

18. Viana JLC and Sant'Ana LLP. Uso de membrana de polipropileno na insta- lação de implante dentário: Relato de Caso Id on Line Rev. Multidisciplinar e de Psi- cologia. 12.42 ( 2018) :943-955.

19. Clementini M., et al. "Success rate of dental implants inserted in autologous bone graft regenerated areas: a systematic review". Oral \& Implant 3.4 (2011): 3-10.

20. Guerrero MD., et al. "Evaluación de la Pérdida Osea y del Éxito/ Fracaso de Implantes de Titanio de Posicionamiento Inmediato y Tardío con Carga Inmediata, Usados para Restauraciones de Arco Completo a 12 Meses de su Implantación". International Journal of Odontostomatology 10.3 (2016): 399-407.

21. Mezzomo LA., et al. "Alveolar ridge preservation after dental extraction and before implant placement: A literature review". Revista Odonto Ciencia 26.1 (2011): 77-83.

22. Primo BT., et al. "Implante imediato para substituição de elemento dentário com fratura radicular: relato de caso clínico". Stomatos 17.32 (2011): 65-71.

23. Calvo-Guirado JL., et al. "Crestal bone reactions to immediate implants placed at different levels in relation to crestal bone. A pilot study in Foxhound dogs". Clinical Oral Implants Research 25.3 (2014): 344-351.

24. Martins SCR., et al. "Minimally Invasive Aesthetic Area Tooth Removal Using Bioextractor ${ }^{\circledR}$ and Immediate Implant Placement with Provisionalization: Case Report". Acta Scientific Dental Sciences 4.6 (2020).
25. Lacerda CCC., et al. "Minimal Invasion and Greater Predictability in Extraction using Bioextractor Followed by Immediate Implantation". SVOA Dentistry 2.4 (2021): 153-160.

26. Cavestro Thais de Oliveira., et al. "Implante imediato com uso da membrana de polipropileno: Relato de caso". Id on Line Rev Psic 12.42 (2018): 1098-1109.

\section{Assets from publication with us}

- Prompt Acknowledgement after receiving the article

- Thorough Double blinded peer review

- Rapid Publication

- Issue of Publication Certificate

- High visibility of your Published work

Website: www.actascientific.com/

Submit Article: www.actascientific.com/submission.php Email us: editor@actascientific.com

Contact us: +919182824667 